\title{
PENERAPAN MODEL PEMBELAJARAN CAROUSEL FEEDBACK DALAM MENINGKATKAN MOTIVASI DAN HASIL BELAJAR
}

\author{
Anselmus Mema ${ }^{1}$, Benedikta Boleng ${ }^{2}$ \\ Universitas Flores ${ }^{1,2}$ \\ anselmus221@gmail.com ${ }^{1}$
}

\begin{abstract}
ABSTRAK
Penelitian ini bertujuan untuk meningkatkan motivasi dan hasil belajar IPS peserta didik kelas IV SDI Watujara Ende. Penelitian ini termasuk Penelitian Tindakan Kelas (PTK) dengan menerapkan dua siklus. Teknik pengumpulan data menggunakan teknik observasi, angket, tes, wawancara, dokumentasi, dan catatan lapangan. Data yang terkumpul dianalisis secara deskriptif kualitatif dan deskriptif kuantitatif. Hasil penelitian menunjukkan bahwa model pembelajaran carousel feedback dapat meningkatkan motivasi, dan hasil belajar. Hal ini dapat dilihat dari peningkatan persentase motivasi belajar siswa yang mencapai kategori tinggi dan sangat tinggi, yaitu $75 \%$ pada siklus I menjadi $83 \%$ pada siklus II. Hasil belajar siswa juga mengalami peningkatan, dilihat dari persentase ketuntasan klasikal yaitu $75 \%$ pada siklus I menjadi $92 \%$ pada siklus II. Simpulan, bahwa setelah diterapkan pembelajaran carousel feedback dapat meningkatkan motivasi dah hasil belajar IPS peserta didik.
\end{abstract}

Kata Kunci: Carousel Feedback, Motivasi, Hasil Belajar

\begin{abstract}
This study aims to improve the motivation and learning outcomes of Social Studies students in grade IV SDI Watujara Ende. This research includes Classroom Action Research (CAR) by applying two cycles. Data collection techniques using observation techniques, questionnaires, tests, interviews, documentation, and field notes. The collected data were analyzed descriptively qualitative and quantitative descriptive. The results showed that the carousel feedback learning model can improve motivation and learning outcomes. This can be seen from the increase in the percentage of students' motivation to achieve high and very high categories, which is $75 \%$ in the first cycle to $83 \%$ in the second cycle. Student learning outcomes have also increased, seen from the percentage of classical completeness that is $75 \%$ in the first cycle to $92 \%$ in the second cycle. Conclusions, that after applying carousel feedback learning can increase motivation and social studies learning outcomes of students.
\end{abstract}

Keywords: Carousel Feedback, Motivation, Learning Outcomes 


\section{PENDAHULUAN}

IPS di SD merupakan mata pelajaran yang memadukan konsep-konsep dasar dari berbagai ilmu sosial yang disusun melalui pendekatan pendidikan dan psikologis serta kelayakan dan kebermaknaannya bagi siswa dan kehidupannya. Ilmu-ilmu sosial dalam IPS SD (khususnya ilmu sejarah, geografi, ilmu ekonomi/koperasi, ilmu politik dan pemerintahan, sosiologi, antropologi dan psikologi sosial) memberikan sumbangan berupa konsep-konsep ilmu yang diubah sebagai "pengetahuan" yang berkaitan dengan kehidupan sosial yang harus dipelajari oleh Peserta didik.

Melalui mata pelajaran IPS, peserta didik diarahkan untuk dapat menjadi warga Negara Indonesia yang demokratis dan bertanggung jawab, serta warga dunia yang cinta damai. Tujuan pembelajaran IPS menurut National Council for the Social Studies (NCSS) yaitu membawa generasi muda sebagai penerus bangsa dalam mengembangkan kemampuannya sehingga menjadi manusia yang berpengetahuan (dalam Ruminiati, 2010).

Pada kenyataannya, guru memposisikan siswa sebagai objek pembelajaran dan memposisikan dirinya sebagai sumber belajar. Hasil observasi awal yang dilakukan pada di kelas IV SDI Watujara Ende diketahui bahwa proses pembelajaran masih didominasi oleh guru. Metode yang digunakan guru hanya ceramah dan penugasan saja. Ketika proses pembelajaran berlangsung peserta didik terlihat kurang antusias dalam mengikuti pembelajaran. Peserta didik malu jika diminta untuk mengungkapkan pendapat, tidak mau maju jika diminta untuk mempresentasikan hasil kerjanya, malu untuk memberikan masukan dan saran kepada teman yang mempresentasikan hasil kerjanya, serta kurang percaya diri dalam mengerjakan tugas yang diberikan guru. Hasil ujian tengah semester peserta didik kelas IV juga kurang memenuhi kriteria ketuntasan minimal (KKM), hanya $40 \%$ siswa yang mencapai KKM, sedangkan $60 \%$ belum mencapai KKM.

Dari identifikasi di atas dapat diketahui bahwa pembelajaran yang dilakukan oleh guru IPS kelas IV tersebut belum mencapai hasil yang optimal. Pembelajaran yang diterapkan juga tidak efektif karena menyebabkan siswa menjadi pasif, tidak termotivasi dalam mengikuti pembelajaran,

Motivasi merupakan dorongan yang memungkinkan siswa untuk bertindak melakukan sesuatu (Sanjaya, 2006). Pada proses pembelajaran, motivasi siswa terlihat melalui ketekunan yang tidak mudah putus asa untuk mencapai suskes meskipun mengalami banyak kesulitan. Motivasi juga ditunjukkan melalui intensitas unjuk kerja dalam melaksanakan tugas. Rendahnya motivasi belajar siswa dapat dilihat berdasarkan pengamatan pada perilaku siswa saat mengikuti proses pelajaran IPS.

Pembelajaran akan berhasil jika peserta didik memiliki motivasi dalam belajar. Oleh karena itu, menumbuhkan motivasi belajar siswa merupakan salah satu tugas dan tanggung jawab guru. Hal ini sejalan dengan yang dikemukan oleh Rasyid dan Mansur (2007) bahwa motivasi peserta didik akan mempengaruhi 
belajar peserta didik jika terdapat lingkungaan yang mendukung. Untuk menciptakan lingkungan yang mendukung diperlukan kemauan dan kemampuan guru untuk menerapkan strategi yang membuat siswa merasa bertanggung jawab terhadap belajar mereka sendiri.

Salah satu upaya yang dapat dilakukan oleh seorang guru untuk menciptakan proses pembelajaran yang lebih efektif adalah dengan menerapkan model pembelajaran yang sesuai. Pemilihan model pembelajaran yang tepat akan memudahkan guru dalam mencapai tujuan pembelajaran yang ditentukan. Pemilihan model pembelajaran carousel feedback karena model pembelajaran ini dapat mengarahkan siswa dalam berpikir kritis serta mampu bertindak aktif dan mandiri. Model pembelajaran carousel feedback dapat melatih peserta didik menghadapi berbagai masalah nyata, melalui proses mencari data sampai memberikan ide/gagasan dan umpan balik kepada kelompok lain. Menurut Kagan dan Kagan (2009) carousel feedback direkomendasikan untuk mengembangkan keterampilan sosial, keterampilan berkomunikasi, pengetahuan, pemrosesan informasi, dan keterampilan berpikir. Ulfa (2017) juga mengungkapkan Alasan pemilihan model Carousel Feedback karena di dalam model ini, siswa dituntut untuk memberikan umpan balik. Dengan adanya umpan balik tersebut siswa dapat mengkaji dan menganalisis jawaban-jawaban yang diberikan oleh kelompok lain dari lembar umpan balik yang ada, sehingga akan menghasilkan sebuah ja-waban yang tidak hanya bersumber dari anggota kelompok saja tetapi juga bersumber dari pemikiran kelompok lain yang tentunya akan menambah pengetahuan kelompok.

Penerapan pembelajaran kooperatif dapat meningkatkan motivasi dan hasil belajar peserta didik. Pembelajaran kooperatif dapat menambah kepercayaan kemampuan berpikir sendiri, menemukan informasi dari berbagai sumber, dan belajar dari siswa yang lain (Sanjaya, 2006). Adapun penelitian yang dilakukan oleh Masrofiq (2013) menunjukkan bahwa penerapan model pembelajaran kooperatif model round table dan carousel feedback dapat meningkatkan motivasi dan hasil belajar siswa.

Mencermati uraian diatas, maka tujuan dari penelitian ini yaitu: 1) Mendeskripsikan penerapan model pembelajaran carousel feedback pada mata pelajaran IPS siswa kelas IV SDI Watujara Ende, 2) Mendeskripsikan penerapan model pembelajaran carousel feedback dalam meningkatkan motivasi belajar peserta didik kelas V SDI Watujara Ende pada mata pelajaran IPS, 3) Mendeskripsikan penerapan model pembelajaran carousel feedback dalam meningkatkan hasil belajar peserta didik kelas IV SDI Watujara Ende pada mata pelajaran IPS, dan 4) Mendeskripsikan tanggapan peserta didik kelas IV SDI Watujara Ende tentang pelaksanaan pembelajaran dengan model pembelajaran carousel feedback pada mata pelajaran IPS. 


\section{METODE PENELITIAN}

Rancangan penelitian yang digunakan adalah penelitian tindakan kelas yang dilakukan secara bersiklus. Pelaksanaan PTK mengacu pada model siklus PTK oleh Kemmis dan Taggart. Setiap siklus terdiri dari atas: 1) planning (perencanaan), 2) acting \& observing (pelaksanaan dan observasi), dan 3) reflecting (refleksi). Hasil refleksi kemudian digunakan untuk memperbaiki perencanaan (revise plan) berikutnya. Jenis penelitian ini dirancang dengan rancangan Penelitian Tindakan Kelas (PTK) dalam bentuk guru sebagai peneliti, maka peneliti bekerja sebagai guru kelas yang merencanakan tindakan, mempersiapkan tindakan, melaksanakan tindakan, dan melaporkan hasil penelitian.

Subjek dalam penelitian yang akan diteliti yaitu peserta didik kelas IV SDI Watujara tahun ajaran 2018/2019 yang berjumlah 20 Peserta didik. Terdiri dari 12 siswa perempuan dan 8 siswa laki-laki.

Sumber data yang digunakan dalam penelitian ini adalah siswa dan guru. Data yang diperlukan yaitu (1) penerapan model pembelajaran carousel feedback, (2) motivasi belajar,dan (3) hasil belajar siswa. Teknik pengumpulan data dalam penelitian ini adalah dengan menggunakan teknik observasi, angket, tes, wawancara, dokumentasi, dan catatan lapangan.

\section{HASIL PENELITIAN}

Penerapan pembelajaran kooperatif model carousel feedback ini dilaksanakan mulai tanggal 12 Maret 2018 sampai dengan 07 April 2018 yang dibagi menjadi dua siklus. Skenario pembelajaran dengan menggunakan model pembelajaran carousel feedback yang diterapkan guru di kelas IV SDI Watujara Ende terlaksana sepenuhnya dengan baik. Hal ini dapat dilihat dari hasil observasi penerapan model pembelajaran carousel feedback. Berdasarkan data yang diperoleh dari instrumen tersebut, ditemukan bahwa penerapan model pembelajaran carousel feedback pada kedua siklus sudah berlangsung maksimal. Pada siklus I, ketercapaian pelaksanaan model pembelajaran carousel feedback adalah $64,2 \%$. Setelah beberapa perbaikan dalam pelaksanaan, maka pada siklus II pelaksanaan model tersebut mengalami peningkatan, yaitu mencapai $83 \%$.

Pada saat pembelajaran awalnya peserta didik berdiskusi secara berkelompok, kemudian berotasi ke kelompok lain untuk mencermati, memberikan umpan balik kepada kelompok lain yang dituliskan dalam lembar feedback. Setelah rotasi tersebut, semua kelompok kembali ke kelompok masingmasing untuk mencermati umpan balik dari kelompok lain. Hal tersebut sudah sesuai dengan langkah-langkah pembelajaran carousel feedback dikembangkan oleh Spencer Kagan. Menurut Kagan dan Kagan (2009), carousel feedback is students interact simultaneously to share ideas of projects. Presentation structures allow efficient sharing of ideas, solutions, or projects. 


\section{Motivasi Belajar}

Penerapan model pembelajaran carousel feedback pada peserta didik kelas IV SDI Watujara Ende terbukti dapat meningkatkan motivasi belajar siswa. Berikut ini disajikan hasil motivasi belajar siswa.

Tabel 1

Hasil Motivasi Belajar Siswa

\begin{tabular}{llllllll}
\hline $\begin{array}{l}\text { Taraf } \\
\text { motivasi } \\
\text { belajar }\end{array}$ & Kategori & \multicolumn{2}{l}{ Pra tindakan } & Siklus I & \multicolumn{2}{c}{ Siklus II } \\
\cline { 2 - 7 } & F & \% & $\mathbf{f}$ & $\mathbf{\%}$ & $\mathbf{f}$ & $\%$ \\
\hline $147-175$ & Sangat tinggi & 0 & 0 & 0 & 0 & 7 & 33 \\
\hline $119-146$ & Tinggi & 5 & 33 & 9 & 75 & 11 & 50 \\
\hline $91-118$ & Cukup & 4 & 42 & 11 & 25 & 2 & 17 \\
\hline $63-90$ & Rendah & 11 & 25 & 0 & 0 & 0 & 0 \\
\hline $35-62$ & Sangat rendah & 0 & 0 & 0 & 0 & 0 & 0 \\
\hline Jumlah & & 20 & 100 & 20 & 100 & 20 & 100 \\
\hline
\end{tabular}

Pada saat proses pembelajaran sebagian besar peserta didik telah berpartisipasi aktif dalam kegiatan diskusi, tampak antusias dalam mengikuti pembelajaran, dan ketika diskusi kelompok peserta didiknbersuara keras dan jelas sehingga diskusi terlihat lebih semangat dan siswa merasa senang.

Di dalam model pembelajaran carousel feedback siswa dituntut untuk selalu aktif dalam kegiatan pembelajaran. Melalui diskusi kelompok, masingmasing anggota harus berusaha memahami materi pelajaran sehingga bisa memberikan kontribusi pada saat diskusi kelompok. Peserta didik juga dituntut untuk mampu mencermati dan memberikan masukan kepada hasil kerja kelompok lain. Hal tersebut bisa menjadi salah satu faktor dari dalam diri peserta didik yang mendorong untuk lebih giat belajar. Ketika peserta didik dan kelompoknya mampu memberikan kontribusi kepada kelompok lain maka akan muncul kebangggaan dan kepuasan dalam belajar. Dorongan untuk bisa memahami materi dan menyampaikan pendapat itulah yang menjadi salah satu faktor intrinsik meningkatnya motivasi belajar. Hal tersebut didukung oleh teori yang dikemukakan Hamalik (2011) bahwa motivasi instrinsik adalah motivasi yang hidup dalam diri siswa dan berguna pada situasi belajar yang fungsional.

\section{Hasil Belajar}

Upaya untuk meningkatkan hasil belajar peserta didik kelas IV SDI Watujara Ende pada mata pelajaran IPS dilakukan dengan menerapkan model pembelajaran carousel feedback. Penerapan model pembelajaran carousel feedback sudah berjalan dengan baik. Hal ini ditunjukkan dengan adanya peningkatan hasil belajar IPS peserta didik, yang dilihat dari nilai akhir setiap siklus. Berikut ini disajikan hasil belajar peserta didik. 
Tabel 2

Hasil Belajar Peserta Didik

\begin{tabular}{lllllll}
\hline \multirow{2}{*}{ Nilai } & \multicolumn{2}{l}{ Pra tindakan } & \multicolumn{2}{l}{ Siklus I } & \multicolumn{2}{l}{ Siklus II } \\
\cline { 2 - 7 } & $\mathbf{f}$ & $\boldsymbol{\%}$ & $\mathbf{F}$ & $\boldsymbol{\%}$ & $\mathbf{f}$ & $\boldsymbol{\%}$ \\
\hline$\geq 70$ & 6 & 50 & 9 & 76 & 19 & 100 \\
\hline$<70$ & 14 & 50 & 11 & 25 & 1 & 8 \\
\hline Jumlah & 20 & 100 & 20 & 100 & 20 & 100 \\
\hline
\end{tabular}

Menurut Kagan \& Kagan (2009), carousel feedback is students interact simultaneously to share idea of projects. Presentation structures allow eficient sharing of ideas, solutions, or projects. Selama proses ini peserta didik bekerjasama untuk menghasilkan tanggapan terhadap pertanyaan yang diajukan, merenungkan tanggapan yang dihasilkan, dan memberikan tanggapan kepada kelompok lain. Peserta didik yang awalnya hanya diam dan tidak memberikan tanggapan dengan melihat temannya yang lain memberikan tanggapan akan ikut bekerjasama untuk memberikan tanggapan terhadap kelompok lain.

Penerapan model ini dipandang efektif karena memberikan ruang partisipasi yang besar kepada peserta didik dalam proses pembelajaran. Anggota kelompok yang terbentuk tidak terlalu banyak sehingga ketika berdiskusi tidak ada yang bermain sendiri, peserta didik aktif dan berpengaruh terhadap hasil belajar yang menjadi baik. Pernyataan ini didukung oleh Silberman (2009) mengemukakan bahwa "salah satu cara terbaik untuk mengembangkan belajar yang aktif adalah memberikan tugas belajar yang diselesaikan dalam kelompok kecil peserta didik." Sejalan dengan hasil penelitian ulfa (2017) dimana hasil pembelajaran meningkat setelah dilakukan pembelajaran menggunakan model carousel feedback pada kompetensi dasar mendeskripsikan gejala (peristiwa) alam yang terjadi di Indonesia dan negara tetangga.

\section{PEMBAHASAN}

Model pembelajaran carousel feedback digunakan sebagai tindak perbaikan dalam penelitian ini terbukti menciptakan suasana pembelajaran yang menyenangkan. Hal ini dapat dilihat dari hasil wawancara peserta didik tentang tanggapan peserta didik kelas V SDI Watujara terhadap penerapan model pembelajaran carousel feedback. Selaras dengan pernyataah ulfa (2017) bahwa Peningkatan hasil belajar tersebut ditandai dengan beberapa hal, antara lain: siswa berani mengungkapkan pendapatnya, siswa berani bertanya apabila ada hal yang kuran dipahaminya dan meningkatkan ketrampilan siswa untuk memecahkan masalah dan bekerja sama dalam kegiatan diskusi.

Berdasarkan uraian diatas diketahui bahwa secara keseluruhan hasil belajar peserta didik mengalami peningkatan dengan diterapkannya model pembelajaran carousel feedback. Peningkatan tersebut dikarenakan siswa merasa senang dan antusias mengikuti pembelajaran. 
Penerapan model tersebut sangat menarik dan memudahkan peserta didik untuk menyelesaikan pekerjannya. Dengan adanya bantuan dari kelompok lain, masalah suatu kelompok bisa diatasi. Model tersebut dipandang menarik karena peserta didik tidak hanya mendengar penjelasan dari guru, tetapi peserta didik sendiri mencari informasi dari peserta didik lain dan berpikir sendiri untuk menyelesaikan pekerjaannya.

Hasil wawancara beberapa sekolah diperoleh informasi siswa merasa senang dengan pembelajaran berbeda. Peserta didik menyenangi model pembelajaran yang diterapkan karena secara aktif melakukan kegiatan belajar, diberikan reward bagi yang aktif, berbagi bersama teman sekelasnya, menjawab pertanyaan teman pada saat diskusi kelas, dan mengajukan pertanyaan ketika kelompok lain presentasi. Menurut siswa dengan penerapan model carousel feedback mengerjakan tugas menjadi lebih mudah karena dikerjakan bersama kelompok.

Hal tersebut didukung dengan pernyataan dari Sanjaya (2006:134), bahwa proses pembelajaran adalah proses yang dapat mengembangkan seluruh potensi siswa. Potensi tersebut dapat berkembang jika peserta didik terbebas dari rasa takut, dan menegangkan. Oleh karena itu perlu diupayakan agar proses pembelajaran merupakan proses yang menyenangkan (enjoyful learning).

\section{SIMPULAN}

Berdasarkan hasil penelitian dan pembahasan, maka dapat disimpulkan bahwa: (1) Penerapan model pembelajaran carousel feedback yang dilakukan terdiri dari langkah-langkah: peserta didik berdiskusi dalam kelompok untuk mengerjakan tugas, berotasi ke kelompok lain untuk mengkritisi dan meninggalkan umpan balik sampai waktu yang ditentukan guru, dan meninjau kembali umpan balik yang diterima tersebut; (2) Penerapan model pembelajaran carousel feedback dapat meningkatkan motivasi belajar peserta didik; (3) Penerapan model pembelajaran carousel feedback dapat meningkatkan hasil belajar peserta didik kelas IV SDK Paupire Ende; (4) Tanggapan peserta didik terhadap penerapan model pembelajaran carousel feedback sangat positif. Peserta didik menyukai model pembelajaran yang diterapkan karena dapat aktif melakukan kegiatan belajar, diberikan reward bagi yang aktif, berbagi bersama teman sekelas, menjawab pertanyaan teman pada saat diskusi kelas, dan mengajukan pertanyaan ketika kelompok lain presentasi. 


\section{DAFTAR PUSTAKA}

Araban, S. (2012). Study of Cooperative Learning Effects on Self-Efficacy and Academic Achievement in English Lesson of High School Students. Journal of Basic and Applied Scientific Research, 2(9).

Depdiknas. (2006). Standar Koempetensi dan Kompetensi Dasar Ilmu pengetahuan dan Teknologi. Jakarta: Badan Standar Nasional Pendidikan.

Hamalik, O. (2011). Proses Belajar Mengajar. Jakarta: Bumi Aksara.

Johnson, D., W \& Johnson, R. T. (2009). An educational Psychology Succes Story: Sosial Interpendence Theory and Cooperative Learning. Jurnal of Education Research, Vol. 38, No.5, June/July2009.

Kagan, S., \& Kagan, M. (2009). Kagan Cooperative Learning. San Clemente: Kagan Publishing.

Masrofiq. (2013). Peningkatan Motivasi Belajar dan Hasil Belajar IPS Melalui penerapan Model Pembelajaran Kooperatif Modell Round Table dan Carousel Feedback (Studi pada kelas VIII B SMP Negeri 2 Krucil Probolinggo). Tesis tidak diterbitkan. Malang: Pascasarjana Universitas Negeri Malang.

Ormrod, J. E. (2008). Psikologi Pendidikan: membantu siswa tumbuh dan berkembang. Jakarta: Erlangga.

Rasyid., H. dan Mansur. (2007). Penilaian Hasil Belajar. Bandung: CV. Wacana Prima.

Sanjaya., W. (2006). Strategi Pembelajaran: Berorientasi Standar Proses Pendidikan. Jakarta: Kencana.

Scunhk, S., E.,D. (2012). Learning Theories An Educational Perspective. Terjemahan Eva Hamdiah dan Rahmat Fajar. Yogyakarta: Pustaka Belajar. 